\title{
DIRASAH
}

Volume 3, Number 1, Februari 2020

p-ISSN: 2615-0212 | e-ISSN: 2621-2838

https://ejournal.iaifa.ac.id/index.php/dirasah

\begin{tabular}{|c|c|c|}
\hline Accepted: & Revised: & Published: \\
Desember 2019 & Januari 2020 & Februari 2020 \\
\hline
\end{tabular}

\section{Pengaruh Gaya Kepemimpinan Tansformational, Authentic, Authoritarian, Transactional Terhadap Kinerja Guru Pesantren di Tangerang}

\author{
Agus Purwanto \\ Universitas Pelita Harapan, Indonesia \\ e-mail:agozpor@gmail.com \\ Masduki Asbari \\ Universitas Pelita Harapan, Indonesia \\ Agus Hari Hadi \\ Institut Pertanian Bogor, Indonesia
}

\begin{abstract}
The purpose of the study was to analyze the influence of leadership style transformational, transactional, authentic and authoritarian to the performance of teachers in a Pesantren Aliyah in Tangerang Central Java. Respondents to the study were 70 teachers and data collection methods by distributing electronic questionnaires to respondents. Data analysis in this study uses SEM (Structural Equation Model) of LISREL program version 8.70. The results of the analysis and processing of research data show that the leadership style of transactional and authorian positively and significantly influence the teacher's performance while the transformational and authentic leadership style is not significant impact on teacher performance.
\end{abstract}

Keywords: Transformational leadership style, Transactional, Authentic and Authoritarian, performance Teacher 


\begin{abstract}
Abstraksi
Tujuan dari penelitian ini adalah untuk menganalisis pengaruh gaya kepemimpinan transformational, transactional, authentic dan authoritarian terhadap kinerja guru di sebuah Pesantren Aliyah di Tangerang Jawa Tengah. Responden dari penelitian ini adalah 70 orang guru dan metode pengumpulan data dengan mendistribusikan kuesioner elektronik kepada para responden. Analisis data dalam penelitian ini menggunakan SEM (Structural Equation Model) program LISREL versi 8.70. Hasil analisis dan pengolahan data penelitian menunjukkan bahwa gaya kepemimpinan transactional dan authorian pada berpengaruh secara positif dan signifikan terhadap kinerja Guru sedangkan gaya kepemimpinan transformational dan authentic tidak berpengaruh signifikan terhadap kinerja guru.
\end{abstract}

Kata kunci: gaya kepemimpinan transformational, transactional, authentic dan authoritarian, kinerja guru

\title{
Pendahuluan
}

Pendidikan di Indonesia makin berkembang dan menghadapi berbagai masalah dan tantangan yang tidak sama dari masa ke masa. Setiap masa memiliki tantangan masing-masing yang harus disikapi dengan evaluasi kebijakan pendidikan tinggi yang dinamis dan kompeten. Masalah Dunia Pendidikan Salah satu masalah mendasar yang dihadapi perguruan tinggi adalah problem relevansi dan mutu yang belum menggembirakan. Pendidikan belum bisa menjadi faktor penting yang mampu melahirkan enterpreneur dengan orientasi job creating dan kemandirian. Pengangguran terdidik dari hasil pendidikan terus bertambah, problem pengabdian masyarakat dimana perguruan tinggi tersebut berada dirasa kurang responsif, dan berkontribusi terhadap problem masyarakat. Kepemimpinan manajerial dan gaya kepemimpinan organisasi sekolah, dalam bentuk organisasi jasa, juga menggunakan sistem manajemen strategi pendidikan nasional berdasarkan Panca Sila dan UndangUndang Dasar Negara Republik Indonesia Tahun 1945 yang berakar pada nilainilai agama, kebudayaan nasional Indonesia dan tanggap terhadap tuntutan zaman $^{1}$.Struktur dan manajemen perguruan tinggi yang berlangsung dalam

1 “Undang-Undang Republik Indonesia No 20 Tentang Sistem Pendidikan Nasional," Jakarta: Direktorat Pendidikan Menengah Umum, pasal 1.

Dirasah, Vol. 3, No. 1, Februari 2020 
hubungan keterkaitan interaktif komunikasinya, selalu dihadapkan pada faktor manusia, baik di dalam proses komunikasi organisasi internal maupun eksternal. Termasuk faktor-faktor diluar kendali manajer itu sendiri yaitu kondisi lingkungan.

Beberapa penelitian sebelumnya yang dimulai dengan topik pengaruh gaya kepemimpinan terhadap kinerja yang telah dilakukan oleh Dwiantoro bahwa jenis gaya kepemimpinan transformational berpengaruh positif dan signifikan terhadap kinerja, tipe gaya kepemimpinan transactional berpengaruh negatif signifikan terhadap kinerja ${ }^{2}$. Lengkong dkk meneliti dampak kepemimpinan transformational pada kinerja karyawan, dan kepemimpinan transactional tidak mempengaruhi kinerja karyawan. Eng dkk. melakukan penelitian dan menyimpulkan bahwa pengaruh gaya kepemimpinan transformational terhadap kinerja. ${ }^{3}$ Gaya kepemimpinan transactional tidak mempengaruhi kinerja. Aqmarina dkk. melakukan penelitian dan menyimpulkan bahwa jenis kepemimpinan transformational negatif dan tidak signifikan mempengaruhi kinerja kepemimpinan transactional karyawan sementara tidak ada pengaruh yang signifikan terhadap kinerja karyawan. ${ }^{4}$ Wahyuniardi dan Nababan melakukan penelitian dan menyimpulkan bahwa jenis kepemimpinan transformational memiliki pengaruh signifikan terhadap kepuasan kerja, jenis kepemimpinan transformational tidak memiliki pengaruh signifikan terhadap kinerja karyawan, budaya organisasi tidak memiliki dampak signifikan terhadap kinerja karyawan, dan kepuasan kerja tidak berpengaruh signifikan terhadap kinerja karyawan. ${ }^{5}$ Untuk meningkatkan kinerja karyawan dapat dilakukan dengan meningkatkan kepuasan kerja jika kepuasan kerja

${ }^{2}$ Faliqul Isbah Dwiantoro, "Pengaruh Gaya Kepemimpinan Tranformasional Dan Tansaksional Tehadap Kinerja Organisasi Melalui Praktik TQM Pada PT. Pelayaran," Jurnal Ilmu Manajemen Volume 5, no. 2 (2017): 1-14.

3 Eng Sun, Handy Aribowo, and Iswati, "Pengaruh Kepemimpinan Transformasional, Kepemimpinan Transaksional Dan Kebijakan Perusahaan Tentang Upah Pekerja Terhadap Produktivitas Kerja (Studi Pada PT 'X' Di Surabaya,' Jurnal Jeksekutif volume 15, no. 2 (2018): 334-55.

${ }^{4}$ Nur Septi Aqmarina, Hamidah Nayati Utami, and Arik Prasetya, "Pengaruh Kepemimpinan Transformasional Dan Kepemimpinan Transaksional Terhadap Kepuasan Kerja Dan Kinerja Karyawan: Studi Kasus Pada Karyawan Hotel Gajah Mada Malang," Volume 35 35, no. 2 (2016): 164-73.

5 Rizki Wahyuniardi and Hepytisa Renaldo Nababan, "Pengaruh Kepemimpinan Transformasional Dan Budaya Organisasi Terhadap Kepuasan Kerja Serta Dampaknya Pada Kinerja Karyawan,” Jurnal Teknik Industri volume 19, no. 2 (2018): 118-226.

Dirasah, Vol. 3, No. 1, Februari 2020 
meningkat, kinerja karyawan juga akan meningkat. Birasnav juga telah meneliti kepemimpinan dan hasil penelitian menunjukkan bahwa jenis kepemimpinan transformational dan model transactional memiliki efek yang kuat dan positif pada kinerja organisasi setelah mengendalikan dampak kepemimpinan transactional. ${ }^{6}$

Al-Musadieq dkk. dalam penelitian sebelumnya menyatakan bahwa pengaruh faktor-faktor organisasional dari desain pekerjaan terhadap peningkatan kinerja staf terbukti signifikan dengan aspek motivasi motivasi kerja, penelitian ini juga menemukan hubungan praktis tidak langsung antara budaya organisasi dan variabel intervening dari motivasi kerja. ${ }^{7}$ Namun Rivai, dkk menyatakan bahwa seorang pemimpin dapat dianggap sebagai pemimpin yang sukses jika berdasarkan pengukuran ia mampu mempengaruhi dan mengembangkan orang-orang yang dipimpinnya. Ciri-ciri yang baik dari seorang pemimpin adalah kepedulian dan peka terhadap kebutuhan orang-orang yang dipimpinnya bahwa bawahan dapat didekati dan bersedia untuk mendiskusikan impian dan harapan mereka. Ada beberapa jenis model kepemimpinan yang tampak dalam organisasi mana pun, ada beberapa yang sangat berpengaruh. Penelitian ini dilakukan untuk melihat kepemimpinan seperti apa yang sangat efektif untuk mempengaruhi kinerja perkuliahan yang akan membawa dampak signifikan pada kinerja semua perkuliahan. Sehubungan dengan berbagai model kepemimpinan, penelitian ini memeriksa apakah kepemimpinan transformational, kepemimpinan transactional, kepemimpinan authentic atau kepemimpinan authoritarian akan secara signifikan mempengaruhi kinerja kuliah di universitas swasta di Tangerang.

Salbiyah menyatakan bahwa sebagaimana diamanatkan dalam UndangUndang Nomor 14 Tahun 2005 tentang guru dan guru, guru dinyatakan sebagai pendidik dan ilmuwan profesional dengan tugas utama mengubah, mengembangkan, dan menyebarluaskan ilmu pengetahuan, teknologi, dan seni melalui pendidikan, penelitian, dan pengabdian kepada masyarakat (Bab 1 Pasal 1 ayat 2). Tugas utama guru adalah melaksanakan tri dharma pendidikan tinggi dengan beban kerja minimal 12 (dua belas) kredit dan maksimum 16 (enam)

${ }^{6}$ M. Birasnav, "Knowledge Management and Organizational Performance in the Service Industry: The Role of Transformational Leadership beyond the Effects of Transactional Leadership," Journal of Business Research volume 67, no. 8 (2014): 1622-29.

${ }^{7}$ Muhammad Al-Musadieq et al., "Influence of Job Design and Organizational Culture against HR Performance," Journal of Management Development volume 37, no. 6 (2018): 452-59.

Dirasah, Vol. 3, No. 1, Februari 2020 
dua belas) kredit di setiap semester sesuai dengan kualifikasi akademik. Pelaksanaan tugas utama guru ini perlu dievaluasi dan dilaporkan secara berkala sebagai bentuk pertanggungjawaban kinerja guru kepada pemangku kepentingan .

Tujuan dari penelitian ini adalah untuk menganalisis pengaruh gaya kepemimpinan transformational, transactional, authentic dan authoritarian terhadap kinerja perkuliahan di beberapa universitas swasta di Tangerang.

Tujuan dari penelitian ini adalah:

1. Menguji dan menganalisis pengaruh kepemimpinan transformational terhadap kinerja kuliah.

2. Menguji dan menganalisis pengaruh kepemimpinan transactional terhadap kinerja kuliah.

3. Menguji dan menganalisis pengaruh kepemimpinan authentic terhadap kinerja kuliah.

Menguji dan menganalisis pengaruh kepemimpinan authoritarian terhadap kinerja kuliah.

\section{Tinjauan Pustaka}

\section{Kepemimpinan}

Rivai dan Mulyadi menyatakan bahwa kata kepemimpinan adalah kemampuan untuk mempengaruhi perilaku orang untuk mencapai tujuan tertentu dalam situasi tertentu. Kepemimpinan selalu berkorelasi dengan kepedulian sosial yang berarti ada interaksi antara pemimpin dengan yang dipimpinnya untuk mencapai tujuan dan sasaran yang sama. ${ }^{8}$

\section{Kepemimpinan transformational}

Bass menyatakan empat komponen transformational: pengaruh ideal pemimpin transformational menjalani hidup mereka untuk dikagumi, dihormati dan dipercaya oleh pengikut mereka; motivasi inspirasional pemimpin transformational memotivasi dan menginspirasi orang-orang di sekitar mereka dengan menawarkan makna, optimisme dan antusiasme untuk visi kondisi masa depan; stimulasi intelektual: pemimpin transformational mendorong pengikut menjadi kreatif dan inovatif untuk menyelesaikan masalah dengan cara baru

8 Veithzal Rivai dan Deddy Mulyadi, Kepemimpinan dan Perilaku Organisasi (Jakarta: Rajawali Pers, 2008) 
dan untuk tidak membuat asumsi; secara individual pemimpin transformational mempertimbangan serta mengusahakan secara aktif potensi pengikut mereka dengan menghasilkan peluang baru untuk pengembangan dan secara konsisten melatih, membimbing, dan memperhatikan kebutuhan dan keinginan pengikut, daripada memantau upaya mereka. ${ }^{9}$ Leithwood menyatakan bahwa gaya transformational menuju kepemimpinan menggarisbawahi emosi dan norma kemudian saling berbagi tujuan dasar untuk memelihara kemajuan kapasitas dan tingkat lanjutan komitmen seseorang terhadap tujuan organisasi. ${ }^{10}$ Erkut membandingkan kepemimpinan transformational dengan kepemimpinan transactional dan menyatakan bahwa hasil kepemimpinan transformational dalam pencapaian yang melebihi apa yang diharapkan. ${ }^{11}$ Lowe menegaskan bahwa dalam meta-analisis dari 39 studi menemukan bahwa individu yang menunjukkan kepemimpinan transformational dibedakan menjadi pemimpin yang lebih efektif dengan produk kerja yang lebih baik daripada mereka yang hanya menunjukkan kepemimpinan transactional. ${ }^{12}$ Krishnan juga memprakarsai gaya kepemimpinan transformational tentunya terkait dengan korespondensi nilai yang serius antara pemimpin dan pengikut. ${ }^{13}$

Yukl menjelaskan bahwa kepemimpinan Transformational menyerukan nilainilai moral dari pengikut dalam upaya mereka untuk meningkatkan kesadaran mereka tentang masalah etika dan untuk memobilisasi energi dan sumber daya mereka ke lembaga reformasi. ${ }^{14}$ Menurut Bass Kepemimpinan transformational didefinisikan sebagai pemimpin yang memiliki kekuatan

9 Bass, Transformational Leadership: Industrial, Military, and Educational Impact (New Jersey: Lawrence Erlbaum Associates, 1998)

${ }^{10}$ Leithwood, K., Louis, K. S., Anderson, S., \& Wahlstrom, K. How Leadership Influences Student Learning (New York: Wallace Foundation,. The, 2004)

${ }^{11}$ Erkutlu, H. The Impact of Transformational Leadership on Organizational and Leadership Effectiveness: the Turkish Case. Journal of Management Development, Volume 27, Nomor 7 (2008), 708-726.

${ }^{12}$ Dumdum, U. R., Lowe, K. B., \& Avolio, B. J. A Meta-Analysis of Transformational and Transactional Leadership Correlates of Effectiveness and Satisfaction: An Update and Extension', Transformational and Charismatic Leadership: The Road Ahead 10th Anniversary Edition (Monographs in Leadership and Management, Volume 5).

13 Krishnan, V., "Transformational Leadership and Outcomes: Role of Relationship Duration", Leadership \& Organization Development Journal, Vol. 26 Nomor 6 (2005). 442457.

14 Yukl, G., \& Mahsud, R.Why Flexible and Adaptive Leadership is Essential. Consulting Psychology Journal: Practice and Research, Volume 62 Nomor 2 (2010), 81-93.

Dirasah, Vol. 3, No. 1, Februari 2020 
untuk mempengaruhi bawahannya dengan cara tertentu, kepemimpinan transformational didefinisikan sebagai pemimpin yang memperkuat kerja sama timbal balik dan pembelajaran tim. ${ }^{15}$ Sementara itu, menurut O'Leary Kepemimpinan transformational adalah gaya kepemimpinan yang digunakan oleh seorang manajer jika ia ingin suatu kelompok memperluas batasannya dan memiliki kinerja di luar status quo atau mencapai serangkaian tujuan organisasi yang sama sekali baru. Pemimpin transformational dapat berhasil mengubah status quo dalam organisasi mereka dengan mempraktikkan perilaku yang sesuai pada setiap tahap proses transformasi. Bass menyatakan bahwa kepemimpinan transformational adalah kepemimpinan yang lebih dari sekadar pertukaran atau penghargaan untuk kinerja yang ditunjukkan oleh pengikut tetapi lebih didasarkan pada kepercayaan dan komitmen. Pemimpin transformational memperhatikan kebutuhan pengembangan masing-masing pengikut dan masalah dengan membantu mereka melihat masalah lama dengan cara baru, dan mereka mampu memotivasi, memelihara, merangsang, membangkitkan, dan menginspirasi pengikut untuk melakukan upaya ekstra untuk mencapai tujuan kelompok. ${ }^{16}$ Kepemimpinan transformational ini benarbenar disebut kepemimpinan sejati karena kepemimpinan ini benar-benar bekerja menuju tujuan yang mengarahkan organisasi ke tujuan yang tidak pernah dicapai sebelumnya. Dengan kepemimpinan transformational, bawahan akan merasa dipercaya, dihargai dan bawahan akan lebih menghargai pemimpin mereka. ${ }^{17}$

Menurut Bass menjelaskan tentang dimensi kepemimpinan transformational, seperti Kharisma adalah kemampuan pemimpin untuk membangkitkan kebanggaan, kepercayaan dan rasa hormat terhadap bawahan mereka dan mampu secara efektif mengkomunikasikan misi dan visi organisasi yang mereka pimpin, menggambarkan sejauh mana seorang pemimpin mengkomunikasikan visi yang menarik, menggunakan simbol untuk

${ }^{15}$ Bernard M. Bass, New Paradigm of Leadership: An Inquiry Into Transformational Leadership (New York: U.S. Army Research Institute for the Behavioral and Social Sciences, 1996).

${ }^{16}$ Grahn, J., Swenson, D. and O’Leary, R. "A comparative analysis between American Indian and Anglo American leadership", Cross Cultural Management: An International Journal, Volume 8, Nomor 1 (2001), 3-20.

${ }^{17}$ Durham, C. C., Knight, D., \& Locke, E. A. Effects of Leader Role, Team-Set Goal Difficulty, Efficacy, And Tactics on Team Effectiveness. Organizational Behavior and Human Decision Processes Journal, Volume 72, Nomor 2 (1997), 203-231.

Dirasah, Vol. 3, No. 1, Februari 2020 
memfokuskan upaya bawahan dan mengekspresikan tujuan penting dengan cara yang sederhana. Rangsangan intelektual, adalah perilaku pemimpin yang mendorong bawahan mereka untuk selalu berinovasi dan menjadi kreatif dalam menyelesaikan masalah yang mereka hadapi, menawarkan ide-ide baru untuk merangsang bawahan mereka untuk memikirkan kembali cara lama menyelesaikan pekerjaan dan mempengaruhi bawahan untuk melihat masalah masalah dari perspektif baru. Pertimbangan individual, adalah perilaku pemimpin yang selalu peduli dengan pengembangan kemampuan bawahan mereka, memperlakukan bawahan sebagai individu, berusaha memahami keinginan bawahan dan berfungsi sebagai penasihat.

\section{Gaya Kepemimpinan Transactional}

Definisi kepemimpinan transactional tidak dapat dipisahkan dari Burn, yaitu kepemimpinan yang berhubungan dengan pengikut yang memotivasi dengan menyerukan kepentingan pribadi mereka ${ }^{18}$. Menurut Yukl kepemimpinan transactional dapat melibatkan nilai-nilai, tetapi nilai-nilai itu relevan dengan proses pertukaran seperti kejujuran, tanggung jawab, dan timbal balik. Bass ${ }^{19}$ mengemukakan bahwa hubungan pemimpin transactional dengan bawahannya tercermin dalam tiga hal, Pemimpin tahu apa yang diinginkan bawahan dan akan menjelaskan apa yang akan diperoleh bawahan jika pekerjaan itu sesuai dengan harapan. Pemimpin bertukar upaya yang dilakukan oleh bawahan sebagai imbalan. Pemimpin responsif terhadap kepentingan pribadi bawahan selama kepentingan itu proporsional dengan nilai pekerjaan yang dilakukan oleh bawahan.

Bass juga berpendapat bahwa karakteristik kepemimpinan transactional terdiri dari dua aspek, imbalan kontingen adalah pemimpin menginformasikan kepada bawahannya tentang apa yang harus dilakukan bawahan mereka jika mereka ingin mendapatkan hadiah tertentu dan menjamin bahwa bawahan akan mendapatkan apa yang mereka inginkan sebagai pengganti upaya yang

${ }^{18}$ Burns J. M. Leadership (New York: Harper \& Row,1978). Baca juga Yukl, G., \& Mahsud, R.Why Flexible and Adaptive Leadership is Essential. Consulting Psychology Journal: Practice and Research, Volume 62 Nomor 2 (2010), 290.

${ }^{19}$ Pradana, Martha Andy. "Pengaruh Gaya Kepemimpinan Transformasional Dan Transaksional Terhadap Kinerja Karyawan (Studi Pada Karyawan Tetap Pt. Mustika Bahana Jaya, Lumajang)." Jurnal Administrasi Bisnis Volume 4 No. 1 (2013).

Dirasah, Vol. 3, No. 1, Februari 2020 
dilakukan. Manajemen pengecualian adalah pemimpin yang berusaha mempertahankan prestasi dan cara kerja bawahannya, jika ada kesalahan, pemimpin tersebut segera bertindak untuk memperbaikinya.

\section{Kepemimpinan Authentic}

Selain kepemimpinan transformational, jenis kepemimpinan hebat lainnya adalah kepemimpinan authentic. Kernis ${ }^{20}$ menyatakan, bahwa kepemimpinan authentic mirip dengan tipe transformational, juga memiliki empat dimensi. Kesadaran diri memiliki sifat berlapis-lapis dari diri yang berisi menemukan wawasan ke dalam diri melalui paparan kepada orang lain dan berkenalan dengan dampak pada orang lain, dengan kata lain kesadaran diri ditunjukkan dengan menunjukkan pemahaman tentang potensi dan keterbatasan setiap orang. Transparansi relasional adalah dimensi kedua yang menghadirkan diri yang otentik kepada orang lain dengan menciptakan kepercayaan melalui keterbukaan yang berarti bersedia berbagi emosi dan pikiran yang paling dalam sambil mengurangi reaksi dan perilaku yang tidak pantas. Pemrosesan yang seimbang dikaitkan dengan para pemimpin yang selalu menganalisis semua data penting secara faktual sebelum membuat keputusan apa pun, mereka meminta gagasan bahwa penilaian sangat dipegang. Yang terakhir adalah perspektif moral yang diinternalisasi, sebagaimana adanya, mengacu pada bentuk pengaturan diri yang terpengaruh dan berasimilasi yang dipandu oleh standar etika internal dan prinsip-prinsip. Dan hasil pengambilan keputusan dan perilaku yang konsisten dengan prinsip-prinsip ini menginternalisasi.

Alavi menyatakan bahwa kepemimpinan authentic memiliki bakat, terutama untuk penyesuaian beragam organisasi karena efisiensi untuk membawa perubahan dengan beberapa metode dalam pengembangan organisasi. Lebih lanjut, menurut Avolio, para pemimpin authentic telah mencapai tingkat keaslian tinggi dalam identitas diri mereka bahwa mereka menerapkan keyakinan kuat mereka terhadap serangkaian nilai sementara jelas berbaur dengan orang lain. Itu menyatakan bahwa kepemimpinan authentic merangsang beberapa cara motivasi dan pembelajaran dalam pengikut selama

\footnotetext{
${ }^{20}$ Haryokusumo, Diaz. "Pengaruh kepemimpinan autentik pada emosi positif, kepercayaan dan harapan serta dampaknya pada komitmen organisasional." Jurnal Bisnis Darmajaya Volume 2 No. 2 (2017): 13-31.
} 
proses perubahan, yang membantu pelaksanaan perubahan yang efektif ${ }^{21}$. Keaslian berarti 'kenalilah dirimu sendiri' diprakarsai oleh filsuf Yunani kuno Socrates yang memiliki pengalaman individual, termasuk persepsi diri tentang pandangannya sendiri, suasana hati, keinginan, kecenderungan, dan teori. Tujuan dari penelitian ini adalah untuk menemukan kompetensi kepemimpinan authentic dibandingkan dengan kepemimpinan transformational dan kepemimpinan authentic terhadap budaya organisasi, motivasi para pekerja untuk membawa hasil dalam kinerja para pekerja.

\section{Kepemimpinan Authoritarian}

Ini mengacu pada perilaku pemimpin dalam menyatakan otoritas yang kuat dan mengatur rekan kerja dan menantang penyerahan yang tidak perlu dipertanyakan dari mereka. Muhumuza ${ }^{22}$, mendefinisikan kepemimpinan authoritarian sebagai gaya kepemimpinan yang ditandai oleh pemimpin yang mempertahankan kekuasaan dan otoritas pengambilan keputusan sebanyak mungkin. Para pemimpin telah menyusun koleksi ganjaran dan hukuman serta mengoperasikan ancaman dan hukuman untuk mengendalikan bawahan, yang idenya hampir tidak pernah terdengar. Zylfija menyatakan bahwa gaya kepemimpinan authoritarian tidak akan memotivasi bawahan, dan menuntut pekerjaan yang harus diselesaikan segera. Para pemimpin ini diyakini sebagai pengendali bahwa bawahan hanya perlu membawa hasilnya berdasarkan spesifikasi pemimpin. Seringkali, pemimpin authoritarian datang dengan solusi yang tidak terlalu inventif, oleh karena itu akan menurunkan pengabdian pengikut terhadap tugas-tugas. Dikonfirmasi oleh Li-Chuan Chu menyatakan studi sebelumnya menunjukkan bahwa perilaku authoritarian pengawas timbul negatif. Ada empat aspek penting menurut Cheng dan Farh dan Cheng, yaitu (1) wewenang dan kontrol, artinya tidak mau mendelegasikan, hanya melibatkan interaksi top-down, mengendalikan data sehingga ragu-ragu, dan sungguh-sungguh memonitor junior, (2) memandang rendah kompetensi bawahan, karena itu tidak akan mendengar ide dan masukan bawahan, (3)

${ }^{21}$ Alavi,Seyyed Babak and Gill, Carol, (2016). Leading Change Authentically: How Authentic Leaders Influence Follower Responses to Complex Change. ournal of Leadership \& Organizational Studies, Issue DOI: 10.1177/1548051816664681, 1- 15.

${ }^{22}$ Muhumuza, M. V., 2015. The Influence Of Authoritarian Leadership On Social, Political And Economic Development: A Comparative Study Of Zambia And Singapore, S.L.: Technical University Of Kenya.

Dirasah, Vol. 3, No. 1, Februari 2020 
membangun citra, yang membuat para pemimpin untuk menjaga harga diri mereka sendiri dengan percaya diri untuk memanipulasi catatan terkait dan (4) perilaku didaktik, yang berarti beberapa tuntutan pada pencapaian dan perilaku tertentu dan jika gagal, teguran dan teguran keras terjadi yang akan menghasilkan emosi negatif pada bawahan, seperti amarah, agresi, dan kecemasan. Keadaan dapat digunakan seperti yang diungkapkan Cherry ketika ada beberapa staf yang tidak terlatih yang bingung bagaimana melakukan atau teknik yang harus diikuti kemudian ada teknik yang kuat namun efektif dapat disampaikan secara detail.

\section{Kinerja Guru}

Salbiyah $^{23}$ menyatakan bahwa berkenaan dengan kinerja dan tanggung jawab guru dalam melaksanakan tugas profesionalnya, kinerja guru melalui tugas dan tanggung jawab guru tercantum dalam Undang-Undang Nomor 14 Tahun 2005, yaitu: (1) Melaksanakan pendidikan, penelitian, dan pengabdian kepada masyarakat, (2) Merencanakan, melaksanakan proses pembelajaran, dan menilai dan mengevaluasi hasil pembelajaran; (3) Terus meningkatkan dan mengembangkan kualifikasi dan kompetensi akademik; (4) Bertindak secara obyektif dan tidak diskriminatif berdasarkan pertimbangan gender, agama, etnis, ras, kondisi fisik tertentu, atau latar belakang sosial ekonomi siswa dalam pembelajaran; (5) Menjunjung tinggi peraturan perundang-undangan, hukum dan kode etik, serta nilai-nilai agama dan etika; dan (6) menjaga dan memelihara kesatuan dan integritas nasional.

Menurut Direktur Jenderal Pendidikan Tinggi ${ }^{24}$, guru memiliki tugas pokok sebagai berikut. Tugas menyelenggarakan pendidikan adalah tugas di bidang pendidikan dan pengajaran, termasuk melakukan kuliah / tutorial dan menguji dan mengatur kegiatan pendidikan di laboratorium, praktik guru, praktik lokakarya / studio / kebun percobaan / teknologi pengajaran, membimbing seminar siswa, membimbing kuliah kerja $(\mathrm{KKN})$, praktik kerja nyata $(\mathrm{PKN})$,

${ }^{23}$ Siti Salbiyah, Fitri Nuraini, Asyidatur Rosmaniar ( 2019 ). Motivation And Its Effect On Women's Lecturer Performance In University of Muhammadiyah Surabaya, SSRG International Journal of Economics and Management Studies (SSRG-IJEMS),6(9), 48-55

${ }^{24}$ Widiawati, Kristiana. "Persepsi Mahasiswa dalam Menilai Kinerja Dosen melalui Evaluasi Umpan Balik Dosen (Eub) di Akademi Sekretari dan Manajemen Bina Insani." Jurnal Administrasi Kantor 2.2 (2014): 345-360. 
praktik kerja lapangan (PKL), memandu tugas akhir penelitian mahasiswa termasuk membimbing, membuat laporan akhir dari hasil penelitian, penguji pada ujian akhir, membina kegiatan siswa di bidang akademik dan bidang kemahasiswaan, mengembangkan program kuliah, mengembangkan bahan ajar, menyampaikan pidato ilmiah, membina kegiatan siswa di bidang akademik dan kemahasiswaan, membimbing guru tingkat bawah, melaksanakan pelatihan guru dan kegiatan transplantasi ${ }^{25}$.

Salbiyah menyatakan bahwa tugas melakukan penelitian adalah tugas di bidang penelitian dan pengembangan karya ilmiah, termasuk menghasilkan karya penelitian, menerjemahkan atau mengadaptasi buku-buku ilmiah, mengedit karya ilmiah, membuat karya desain dan teknologi, menciptakan desain seni. Tugas melakukan pengabdian masyarakat mencakup menduduki posisi kepemimpinan di lembaga pemerintah / pejabat negara sehingga mereka harus dilepaskan dari posisi organik mereka, melaksanakan pengembangan hasil pendidikan dan penelitian yang dapat dimanfaatkan oleh masyarakat, memberikan pelatihan / konseling / peningkatan ke masyarakat, memberikan layanan kepada masyarakat atau kegiatan lain yang mendukung pelaksanaan pemerintahan umum dan tugas pembangunan, membuat dan menulis layanan masyarakat. Tugas mendukung tiga-tri dharma pendidikan tinggi termasuk menjadi anggota komite / badan di pendidikan tinggi, menjadi anggota komite / badan di lembaga pemerintah, menjadi anggota organisasi profesional, mewakili lembaga tersier / lembaga pemerintah duduk di komite antar lembaga, menjadi anggota delegasi nasional untuk pertemuan internasional, berpartisipasi dan aktif dalam pertemuan ilmiah, mendapatkan penghargaan layanan, penghargaan, menulis buku teks sekolah menengah atas, memiliki prestasi di bidang olahraga, seni, sosial.

\section{Metode}

Analisis data penelitian ini menggunakan Structural Equation Model (SEM) menggunakan Linear Structural Model (LISREL) versi 8.70. metode pengumpulan data dengan memberikan kuesioner elektronik kepada seluruh guru. Responden penelitian adalah guru disebuah Pesantren Aliyah di Tangerang sebanyak 70 orang.

25 ibid

Dirasah, Vol. 3, No. 1, Februari 2020 
Tabel 1 Profil Responden Guru

\begin{tabular}{|c|c|c|c|}
\hline Masa Kerja & Laki-laki & Perempuan & Total \\
\hline $0-3$ Tahun & 14 & 16 & 30 \\
\hline $3-6$ Tahun & 12 & 8 & 20 \\
\hline $6-10$ Tahun & 4 & 2 & 6 \\
\hline Lebih dari 10 Tahun & 8 & 6 & 14 \\
\hline \multicolumn{2}{|c|}{ T O T A L } & 70 \\
\hline
\end{tabular}

Catatan : Tabel profil responden berasal dari ringkasan kuesioner yang dikembalikan

Berdasarkan penelitian sebelumnya dan tujuan penulisan penelitian ini, maka akan dibuat model penelitian sebagai berikut:

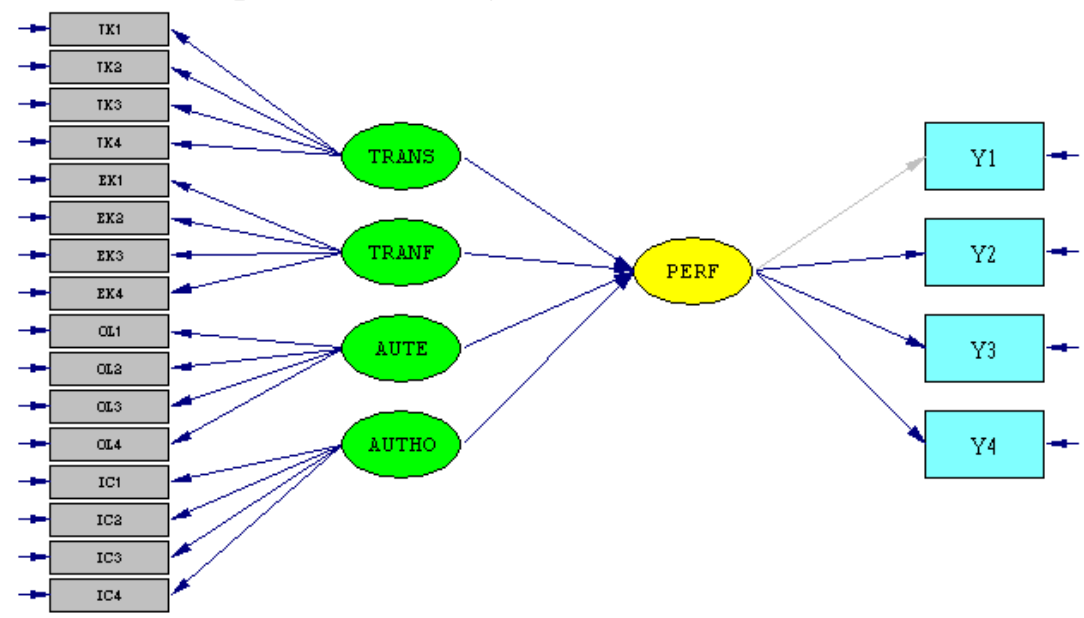

\section{Gambar 1 Model Penelitian}

Catatan : Gambar 1 berasal dari output program Lisrel

Berdasarkan model penelitian di atas akan dibuat hipotesis berikut :

1. H1 : Ada hubungan yang signifikan antara Kepemimpinan Transactional (TRANS) dengan Kinerja Guru (PERF).

2. H2 : Ada hubungan yang signifikan antara Kepemimpinan Transformational (TRANS) dengan Kinerja Guru (PERF).

3. H3 : Ada hubungan yang signifikan antara Kepemimpinan Authentic (TRANS) dengan Kinerja Guru (PERF).

4. H4 : Ada hubungan yang signifikan antara Kepemimpinan Authoritarian (TRANS) dengan Kinerja Guru (PERF). 
Distribusi data kuesioner elektronik dilakuakn dari bulan November hingga Desember 2019 di Pesantren Aliyah di Tangerang.

\section{Hasil Dan Diskusi}

Langkah pertama adalah membuat program sintaks pada software Lisrell setelah itu program dijalankan untuk mendapatkan faktor pemuatan Kepemimpinan Transactional (TRANS), Kepemimpinan Transformational (TRANS), Kepemimpinan Authentic (TRANS), Kepemimpinan Authoritarian (TRANS), dan Kinerja Kuliah (PERF). Analisis data dilakukan oleh Structural Equation Model (SEM) menggunakan Linear Structural Model (LISREL) versi 8.70 dari Joreskog dan Sorbom (2008), dan hasilnya adalah dalam gambar berikut :

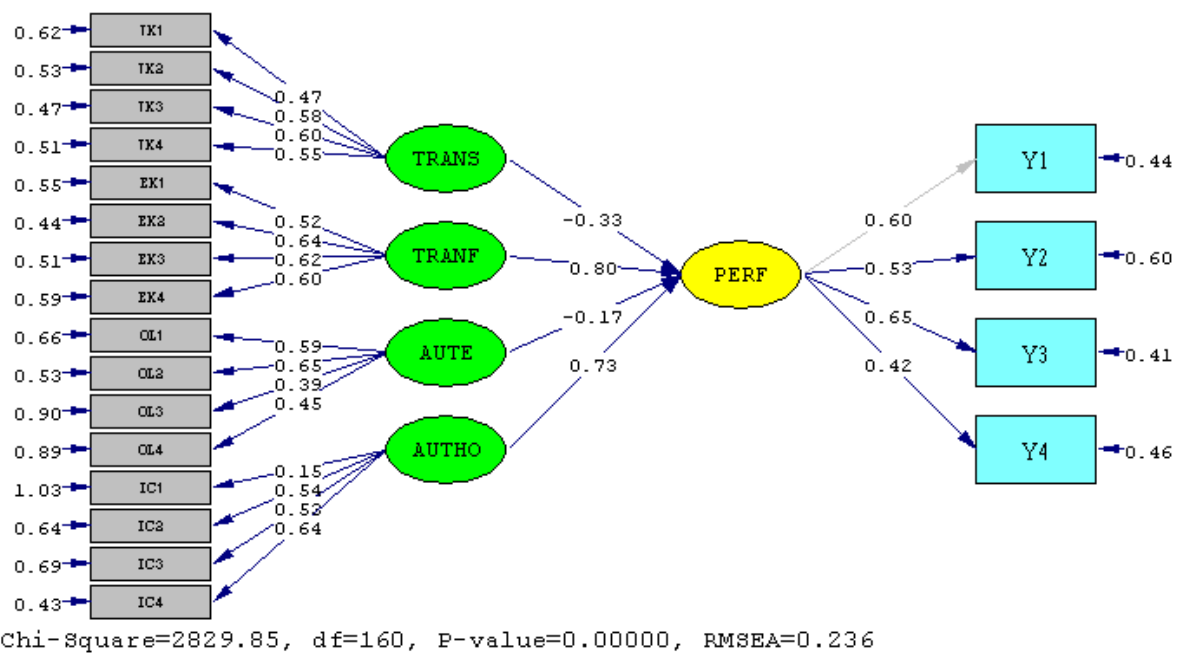

Ganbar 2 Memuat Nilai Indikator

Catatan : Gambar berasal dari proses output program Lisrel 


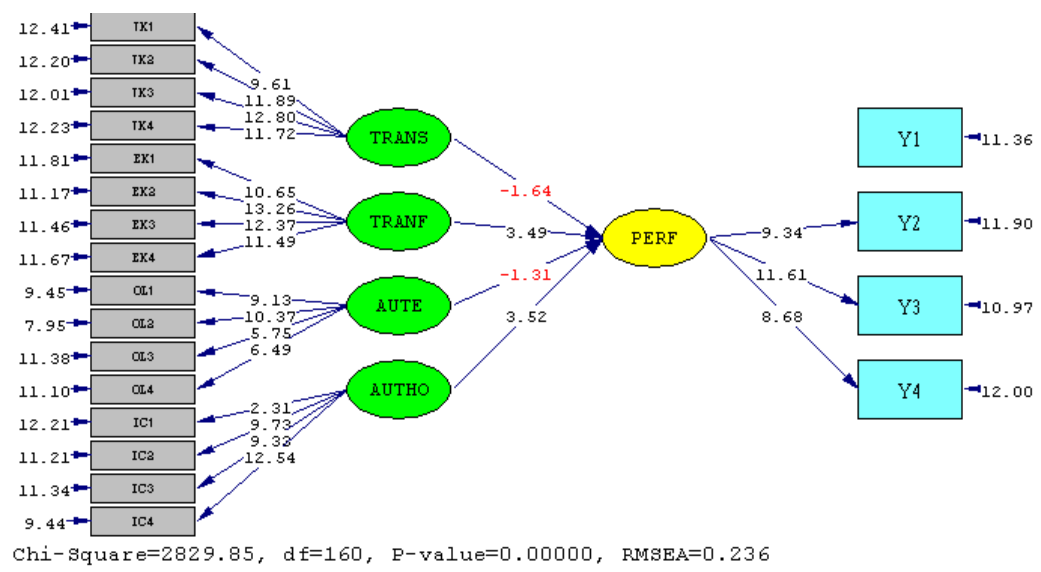

\section{Gambar 3. Idikator Nilai - $t$}

Catatan : Gambar berasal dari proses output program Lisrel

Berdasarkan gambar 2 dan gambar 3 disimpulkan bahwa tidak ada nilai varians nilai negatif, dan nilai indikator Kepemimpinan Transactional (TRANS), Kepemimpinan Transformational (TRANS), Kepemimpinan Authentic (TRANS), Kepemimpinan Authoritarian (TRANS), dan Kinerja Kuliah (PERF) ) di atas loading factor $0,5(>0,5)$ Kemudian hasil output lisrell dari masingmasing indikator dan loading factor dirangkum dalam tabel untuk analisis validitas dan reliabilitas. Ringkasan hasil analisis dapat dilihat pada tabel berikut:

Tabel 2a. Hasil Indikator Analisis Order 2 CFA Membangun Validitas

\begin{tabular}{|c|c|c|c|c|}
\hline Variabel & Indikator & $\begin{array}{l}\text { Loading } \\
\text { Factor }\end{array}$ & $\begin{array}{c}T- \\
\text { Value }\end{array}$ & Keterangan \\
\hline \multirow{4}{*}{$\begin{array}{l}\text { Kepemimpinan } \\
\text { Transactional } \\
\text { ( TRANS) }\end{array}$} & TRANS 1 & 0.47 & 9.61 & Valid \& Sig \\
\hline & TRANS 2 & 0.58 & 11.89 & Valid \& Sig \\
\hline & TRANS 3 & 0.60 & 12.80 & Valid \& Sig \\
\hline & TRANS 4 & 0.65 & 11.72 & Valid \& Sig \\
\hline \multirow{4}{*}{$\begin{array}{l}\text { Kepemimpinan } \\
\text { Transformational } \\
\text { (TRANF) }\end{array}$} & TRANF 1 & 0.52 & 10.65 & Valid \& Sig \\
\hline & TRANF 2 & 0.64 & 13.26 & Valid \& Sig \\
\hline & TRANF 3 & 0.62 & 12.37 & Valid \& Sig \\
\hline & TRANF 4 & 0.60 & 11.49 & Valid \& Sig \\
\hline Kepemimpinan & AUTE 1 & 0.59 & 9.13 & Valid \& Sig \\
\hline
\end{tabular}




\begin{tabular}{|c|c|c|c|c|}
\hline \multirow{3}{*}{$\begin{array}{l}\text { Authentic } \\
\text { ( AUTE) }\end{array}$} & AUTE 2 & 0.65 & 10.37 & Valid \& Sig \\
\hline & AUTE 3 & 0.39 & 5.75 & Valid \& Sig \\
\hline & AUTE 4 & 0.45 & 6.49 & Valid \& Sig \\
\hline \multirow{4}{*}{$\begin{array}{l}\text { Kepemimpinan } \\
\text { Authoritarian } \\
\text { (AUTHO) }\end{array}$} & AUTHO 1 & 0.55 & 2.31 & Valid \& Sig \\
\hline & AUTHO 2 & 0.54 & 9.73 & Valid \& Sig \\
\hline & AUTHO 3 & 0.53 & 9.32 & Valid \& Sig \\
\hline & AUTHO 4 & 0.64 & 12.54 & Valid \& Sig \\
\hline
\end{tabular}

Catatan : Tabel berasal dari proses output program Lisrel

Berdasarkan hasil pengujian di atas menunjukkan bahwa nilai loading factor diperoleh seluruhnya di atas 0,5 (>0,5), dan semua nilai t yang diperoleh lebih signifikan dari 1,96 (> 1,96). Ringkasan hasil analisis di atas dapat dilihat pada Tabel 3.

\section{Tabel 3 Analisis Untuk Order 2 CFA OCB Validitas}

\begin{tabular}{|l|l|l|l|}
\hline Variabel & Loading Factor & T-Value & Keterangan \\
\hline $\begin{array}{l}\text { Kepemimpinan Transactional } \\
\text { Kepemimpinan }\end{array}$ & -0.33 & -1.64 & No Significant \\
Transformational & 0.80 & 3.49 & Significant \\
Kepemimpinan Authentic & -0.17 & -1.31 & No Significant \\
Kepemimpinan Authoritarian & 0.73 & 3.52 & Significant \\
\hline
\end{tabular}

Catatan : Tabel berasal dari proses output program Lisrell

Hasil ini dapat disimpulkan bahwa kepemimpinan transactional tidak berpengaruh signifikan terhadap kinerja perkuliahan, kepemimpinan transformational berpengaruh signifikan terhadap kinerja perkuliahan, kepemimpinan authentic tidak berpengaruh signifikan terhadap kinerja perkuliahan, kepemimpinan authoritarian berpengaruh signifikan terhadap kinerja perkuliahan.

Tabel 4 Hasil Analisis Order 2 Reliabilitas

\begin{tabular}{|c|c|c|c|c|}
\hline Indikator & $\begin{array}{c}\text { Loading } \\
\text { Factor2 }\end{array}$ & $\begin{array}{c}\text { 1-Loading } \\
\text { Factor2 }\end{array}$ & CR & VE \\
\cline { 1 - 4 } TRANS 1 & 0.47 & 0.58 & 0.76 & 0.63 \\
\hline
\end{tabular}




\begin{tabular}{|c|c|c|}
\hline TRANS 2 & 0.58 & 0.69 \\
\hline TRANS 3 & 0.60 & 0.62 \\
\hline TRANS 4 & 0.65 & 0.85 \\
\hline TRANF 1 & 0.52 & 0.95 \\
\hline TRANF 2 & 0.64 & 0.39 \\
\hline TRANF 3 & 0.62 & 0.42 \\
\hline TRANF 4 & 0.60 & 0.31 \\
\hline AUTE 1 & 0.59 & 0.36 \\
\hline AUTE 2 & 0.65 & 0.44 \\
\hline AUTE 3 & 0.39 & 0.45 \\
\hline AUTE 4 & 0.45 & 0.46 \\
\hline AUTHO 1 & 0.55 & 0.57 \\
\hline AUTHO 2 & 0.54 & 0.46 \\
\hline AUTHO 3 & 0.53 & 0.47 \\
\hline AUTHO 4 & 0.64 & 0.56 \\
\hline PERF 1 & 0.47 & 0.48 \\
\hline PERF 2 & 0.58 & 0.49 \\
\hline PERF 3 & 0.60 & 0.56 \\
\hline PERF 4 & 0.65 & 0.54 \\
\hline
\end{tabular}

Catatan : Tabel berasal dari proses output program Lisrell

Berdasarkan rumus perhitungan reliabilitas konstruk CR diperoleh hasil dan indikator $\mathrm{VE}$ adalah $0,76(\mathrm{CR}) \geq 0,70$ dan 0,63 (VE) $\geq 0,50$. dan disimpulkan bahwa variabel reliabilitas baik dan konstruk nilai memiliki reliabilitas baik. Oleh karena itu, berdasarkan hasil analisis perhitungan reliabilitas dapat disimpulkan bahwa reliabilitas keseluruhan merupakan indikator yang baik dan menyimpulkan bahwa penelitian memenuhi persyaratan semua fase pengujian. Langkah selanjutnya adalah melakukan Analisis Goodness of Fit (GOF), data GOF diperoleh dari hasil eksekusi software.

\section{Analisis Goodness Of Fit (GOF)}

Uji kesesuaian model pada keseluruhan model fit tentang analisis statistik nilai GOF yang dihasilkan oleh program Lisrell, untuk relevansi model (model fit) yang cukup baik dan untuk modelnya sesuai dengan kriteria seperti yang ditunjukkan pada Tabel 5. 
Tabel 5 Goodness Of Fit

\begin{tabular}{|l|c|c|c|}
\hline Indeks Fit & Nilai & Standar Nilai & Keterangan \\
\hline Chi-Square & 80.19 & $>0.5$ & Fit \\
\hline $\begin{array}{l}\text { Root Mean Square Error of } \\
\text { Approximation (RMSEA) }\end{array}$ & 0.05 & $<0.08$ & Fit \\
\hline Normed Fit Index (NFI) & 0.91 & $>0.90$ & Fit \\
\hline Non-Normed Fit Index (NNFI) & 0.92 & $>0.90$ & Fit \\
\hline Comparative Fit Index (CFI) & 0.92 & $>0.90$ & Fit \\
\hline Incremental Fit Index (IFI) & 0.91 & $>0.90$ & Fit \\
\hline Relative Fit Index (RFI) & 0.91 & $>0.90$ & Fit \\
\hline Goodness of Fit Index (GFI) & 0.91 & $>0.90$ & Fit \\
\hline
\end{tabular}

Catatan : Tabel berasal dari proses output program Lisrell

Berdasarkan hasil analisis di atas dapat diketahui bahwa semua indeks fit menyatakan bahwa model fit. Hasil ini menunjukkan bahwa variabel tersebut dinyatakan valid dan dapat diandalkan sehingga dapat disimpulkan bahwa keseluruhan model masih cocok. Model persamaan (Structural Equations) linier dari 8.70 perangkat lunak LISREL diperoleh sebagai berikut:

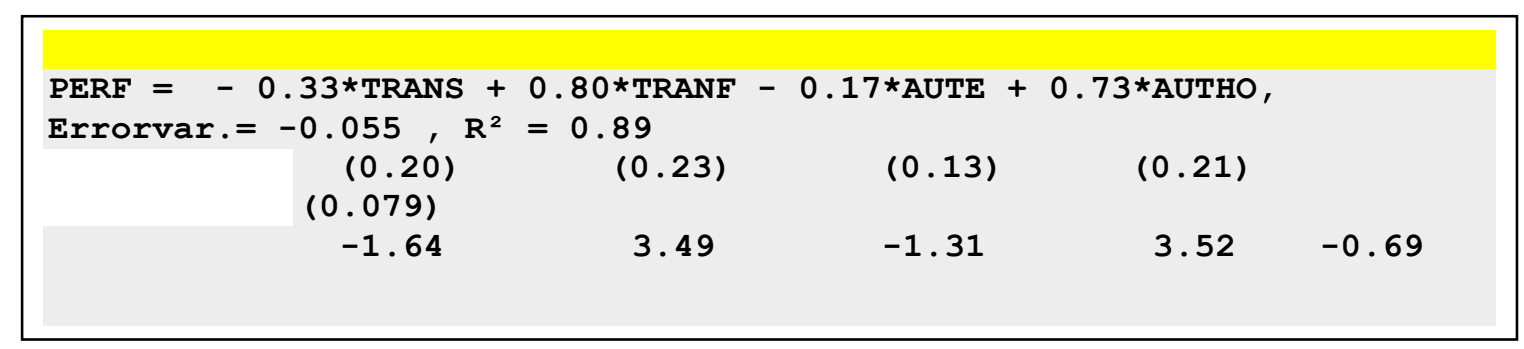

\section{Gambar 4 Persamaan Struktural}

Catatan : Gambar berasal dari proses output program Lisrell

Berdasarkan hasil dari semua analisis di atas, dapat diringkas dan diperoleh persamaan regresi berikut (Kinerja Kuliah) $=-0,33 *$ TRANS $+0,80$ $*$ TRANF $-0,17 *$ AUTE $+0,73 *$ AUTHO, Errorvar. $=-0,055$ 


\section{Diskusi Dan Kesimpulan}

Berdasarkan analisis hasil penelitian dapat disimpulkan bahwa tidak terdapat pengaruh yang signifikan Kepemimpinan Transactional (TRANS) terhadap Kinerja Guru (PERF), Tidak ada pengaruh yang signifikan Kepemimpinan Transformational (TRANS) terhadap Kinerja Guru (PERF). Tidak ada pengaruh signifikan Kepemimpinan Authentic (TRANS) terhadap Kinerja Kuliah (PERF). Terdapat pengaruh yang signifikan antara Kepemimpinan Authoritarian (TRANS) dengan Kinerja Kuliah (PERF). Purwanto melakukan penelitian dan menyimpulkan bahwa kepemimpinan transformational dan kepemimpinan transactional memiliki pengaruh positif dan signifikan terhadap kinerja bisnis. Asbari menyatakan bahwa efek transformational juga memiliki pengaruh yang signifikan terhadap kinerja kerja. Mirayani kepemimpinan authentic dan authoritarian memiliki pengaruh signifikan terhadap kinerja kerja.

Alonderiene melakukan penelitian empiris mengungkapkan dampak positif yang signifikan dari gaya kepemimpinan pada kepuasan kerja fakultas di mana gaya kepemimpinan pelayan telah ditemukan memiliki dampak signifikan positif tertinggi pada kepuasan kerja fakultas sementara mengendalikan gaya kepemimpinan autocrat memiliki dampak terendah. Martin menyatakan bahwa pengaruh kepemimpinan di enam bidang utama muncul sebagai signifikan dalam penelitian: manajer lingkungan, manajer jaringan, manajer kebijakan, manajer krisis, manajer kesenjangan pengetahuan, dan persiapan pemimpin masa depan. Para penulis menegaskan bahwa pemimpin memiliki kontrol yang luar biasa terhadap lingkungan pemrosesan pengetahuan dan peran kepemimpinan memiliki pengaruh yang lebih luas daripada resolusi kesenjangan pengetahuan. Garger menemukan bahwa studi tentang kepemimpinan authentic relatif baru; definisi kerja, metode pengukuran, dan studi berbasis kriteria belum ada. Dengan demikian, upaya untuk mengembangkan pemimpin authentic hanya dapat menghasilkan pemimpin yang dilatih untuk menunjukkan perilaku kepemimpinan authentic secara dangkal. 
Penelitian $\mathrm{Liu}^{26}$ memberikan bukti empiris bahwa kepemimpinan authentic berhubungan positif dengan perilaku proaktif bawahan dan berhubungan negatif dengan perilaku penyimpangan tempat kerja bawahan melalui efek mediasi dari tiga faktor psikologis, termasuk identifikasi supervisor, keselamatan psikologis, dan keterlibatan kerja. William menemukan hasil dari latihan penelitian ini menunjukkan bahwa kepala sekolah perguruan tinggi menunjukkan perilaku transactional jauh lebih sering daripada tindakan transformational yang terkait dengan distribusi model kepemimpinan authentic. Hasil ini dapat dijelaskan dalam hal tekanan yang bekerja pada pendidikan yang semakin kompetitif dan tidak merata. Singkatnya, Kepala Sekolah bertindak pragmatis dan instrumental untuk mencapai tujuan jangka pendek mereka. Penelitian Flumerfelt mengidentifikasi enam peringkat tinggi, dan tujuh paradigma kepemimpinan yang sangat terkait. Paradigma yang memiliki peringkat paling tinggi dan paling terkait adalah menghadapi ambiguitas. Temuan ini menyoroti bahwa meningkatkan paradigma kepemimpinan adalah penting.

\section{Pembatasan}

Penelitian ini memiliki beberapa keterbatasan, sampel tidak mewakili populasi target, jumlah sampel yang tidak banyak karena keterbatasan waktu dan biaya, objek penelitian ini hanya sebuah Pesantren Aliyah. Waktu penelitian yang terbatas dan jumlah responden yang hanya 70 orang belum yakin untuk menggeneralisasi hasil penelitian. Software yang digunakan untuk analisis data adalah Lisrell dan banyak orang belum terbiasa dengan software ini. Untuk penelitian selanjutnya dapat memperluas responden di Sekolah umum dan di tempat lain.

\section{Daftar Pustaka}

Alavi,Seyyed Babak and Gill, Carol, (2016). Leading Change Authentically: How Authentic Leaders Influence Follower Responses to Complex Change. ournal of Leadership \& Organizational Studies, Issue DOI: 10.1177/1548051816664681, 1- 15.

\footnotetext{
${ }^{26}$ Nurfaizal, Yusmedi. "Peran Modal Psikologis Kreatif Dalam Membangun Perilaku Kreatif."
}

Dirasah, Vol. 3, No. 1, Februari 2020 
Alonderiene, R. and Majauskaite, M. (2016), "Leadership style and job satisfaction in higher education institutions", International Journal of Educational Management, Vol. 30 No. 1, pp. 140-164. https://doi.org/10.1108/IJEM-08-2014-0106

Al-Musadieq, Muhammad, Nurjannah, Raharjo, Kusdi,Solimun and Fernandes, Adji Achmad Rinaldo, (2018). "The mediating effect of work motivation on the influence of job design and organizational. Journal of Management Development, 10( Emerald Publishing Limited). Anon., n.d. Beverly Alimo-Metcalfe and Robert J. Alban-Metcalfe, 2001. The development of a new Transformational Leadership Questionnaire. Journal of Occutangerangonal and Organizational Psychology, 74(The British Psychological Society), pp. 1-27.

Asbari, M., Santoso, P., \& Purwanto, A. (2019). Pengaruh Kepemimpinan dan Budaya Organisasi Terhadap Perilaku Kerja Inovatif Pada Industri 4.0. JIM UPB (Jurnal Ilmiah Manajemen Universitas Putera Batam), 8(1), 7-15. doi: https://doi.org/10.33884/jimupb.v8i1.1562

Asbari, M., Nurhayati, W., \& Purwanto, A. (2019). Pengaruh Parenting style dan Personality Genetic Terhadap Pengembangan Karakter Anak di Paud Islamic School. JURNAL AUDI: Jurnal Ilmiah Kajian Ilmu Anak dan Media Informasi PAUD, 4(2), 148163.http://ejurnal.unisri.ac.id/index.php/jpaud/article/view/3344

Asbari, M., Santoso, P., \& Purwanto, A. (2019). Pengaruh Iklim Organisasi dan Kepemimpinan Transformasional Terhadap Produktivitas Kerja Inovatif Pada Industri Manufaktur di Tangerang Jawa Tengah. Jurnal Produktivitas Universitas Muhammadiyah Pontianak, 7(1 2020), 6269. doi: DOI : 10.29406/jpr.v7i1.1797

Asbari. M.,Nurhayati. W.,Purwanto.A,. (2020).The effect of parenting style and genetic personality on children character development. Jurnal Penelitian dan Evaluasi Pendidikan : 23(2). DOI: https://dx.doi.org/10.21831/pep.v23i2.28151

Bosch, D., (2013). The Impact of Transformational Leadership on LeaderFollower Work Value Congruence. International Journal of Business and Social Research (IJBSR),, Volume vol. 3 no 8, pp. 18-31.

Chukwusa, J., (2019). Autocratic Leadership Style: Obstacle to Success in Academic Libraries. Library Philosophy and Practice e-Journal, Issue 
DigitalCommons@University of Nebraska - Lincoln. Chu, L.-C., 2013. The moderating role of authoritarian leadership on the relationship between the internalization of emotional regulation and the well-being of employees. Leadership, Issue DOI: $10.1177 / 1742715013498403,1-18$.

Corbin, B., (2000). Entrepreneurial Leadership: Fundamentals. Carmel: Corbin Group Publishing. Erkutlu, H., 2008. The impact of transformational leadership on organizational and leadership effectiveness. Journal of Management Development, Vol. 27 (No. 7), 708-726.

C. E.María, L.S. Vijande, "Reasons and constraints to implementing an ISO 22000 food safety management system: Evidence from Spain". Food Control Journal, 2014;40: 50-57, https://doi.org/10.1016/j.foodcont.2013.11.032

E.S.Ong, H. Ariwibowo, Isnawati, "Pengaruh Kepemimpinan Transformasional, Kepemimpinan Transaksional Dan Kebijakan Perusahaan Tentang Upah Pekerja Terhadap Produktivitas Kerja (Studi Pada PT “X” Di Surabaya)". Jurnal Jeksekutif, 2018;5: 334-335, https://jurnal.ibmt.ac.id/index.php/jeksekutif/article/view/200/168

Fachreza, Said Musnadi, M. Shabri Abd Majid, (2018). Pegaruh Motivasi kerja,Lingkungan Kerja,Dan Budaya Organisasi Terhadap Kinerja Karyawan Dan Dampaknya Pada Kinerja Bank. jurnal Magister Manajemen ISSN 2302-0199.

Fadhil, Achmar dan Mayowan, Yuniadi, (2018). Pengaruh Motovasi Kerja dan Kepuasan Kerja Terhadap Kinerja Karyawan AJB Bumiputra. Jurnal $(J A B)$, vol 54 (no 1).

L. Macheka, F. A. Manditsera, R.T. Ngadze, J. Mubaiwa, L. K. Nyanga, "Barriers, benefits and motivation factors for the implementation of food safety management system in the food sector in Harare Province, Zimbabwe". Food Control Journal, 2013;34: 126-131, https://doi.org/10.1016/j.foodcont.2013.04.019

N.S. Aqmarina, H.N. Utami, A. Prasetya," Pengaruh Kepemimpinan Transformasional Dan Kepemimpinan Transaksional Terhadap Kepuasan Kerja Dan Kinerja Karyawan ( Studi Kasus Pada Karyawan Hotel Gajah Mada Malang)". Jurnal Administrasi Bisnis,2016;35:164-

Dirasah, Vol. 3, No. 1, Februari 2020 
173,

http://administrasibisnis.studentjournal.ub.ac.id/index.php/jab/article/vi $\underline{\text { ew/1382 }}$

Firdaus, R.A.,Purnamasari, D., Akuba, S.F.(2019) The influence of motivation, leadership and perceived workload as intervening on teacher commitment. Journal of Education and Science Technology, 5(3) . DOI : https://doi.org/10.26858/est.v5i3.10847

F.I.Dwiantoro, "Pengaruh Gaya Kepemimpinan Tranformasional dan Tansaksional Tehadap Kinerja Organisasi Melalui Praktik TQM Pada PT. Pelayaran". Jurnal Ilmu Manajemen, 2017; 05:1-14, https://jurnalmahasiswa.unesa.ac.id/index.php/jim/article/download/19 $\underline{175 / 17509+\& c d=4 \& h l=j v \& c t=c l n k \& g l=i d}$

Flumerfelt, S. and Banachowski, M. (2011), "Understanding leadership paradigms for improvement in higher education", Quality Assurance in Education, $\quad$ Vol. 19 No. 3, pp. 224-247. https://doi.org/10.1108/09684881111158045

F.Rahim, V. P.K. Lengkong, L. O.H. Dotulong, "Pengaruh Kepemimpinan Transformational Dan Kepemimpinan Transaksional Terhadap Kinerja Karyawan Pada PT. PLN Wilayah Sulutenggo". Jurnal EMBA, 2018;4: 3503 -3512 , https://ejournal.unsrat.ac.id/index.php/emba/article/viewFile/21623/21 $\underline{326}$

Garger, J. (2008), "Developing authentic leadership in organizations: some insights and observations", Development and Learning in

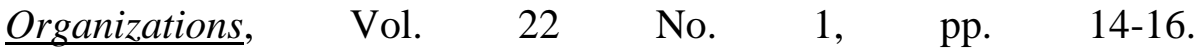
https://doi.org/10.1108/14777280810840058

Kotzé, Martina and Nel, Petrus, (2017). Personal factor effects on authentic leadership. Journal of Psychology in Africa, Vol. 27, No. 1(Africa Scholarship Development Enterprize), p. 47-53.

Lee, C. S., (2018). Authentic Leadership and Organizational Effectiveness: The Roles of Hope, Grit, and Growth Mindset. International Journal of Pure and Applied Mathematic, Volume 118 no 19(Special), pp. 383401. 
Liu, Y., Fuller, B., Hester, K., Bennett, R. and Dickerson, M. (2018), "Linking authentic leadership to subordinate behaviors", Leadership \& Organization Development Journal, Vol. 39 No. 2, pp. 218-233. https://doi.org/10.1108/LODJ-12-2016-0327

Mboya,Millicent Atieno , Were,Susan And Otieno,Romanus Odhiambo , Month: October 2017 - March 2018. Effect Of Autocratic Leadership Style On Quality Assurance In Institutions Of Higher Learning In Kenya. International Journal of Management And Commerce Innovations, Volume Vol. 5, Issue 2, Pp. 1214-1225.

Muhumuza, M. V., 2015. The Influence Of Authoritarian Leadership On Social, Political And Economic Development: A Comparative Study of Zambia And Singapore, S.L.: Technical University Of Kenya.

Mirayani, R., S.Williana Kusumaningsih, \& Anggaripeni Mustikasiwi. (2019). Transformational, Authentic, And Authoritarian Types Of Leadership: Which One Is The Most Influential In Staffs' Performance (A Study On Performance In A Religious School Setting). Dinasti International Journal Of Education Management And Social Science, 1(2), 172-182. https://doi.org/10.31933/dijemss.v1i2.68

Martin, J. and Marion, R. (2005), "Higher education leadership roles in knowledge processing", The Learning Organization, Vol. 12 No. 2, pp. 140-151. https://doi.org/10.1108/09696470510583520

M.Birasnav, "Knowledge management and organizational performance in the service industry: The role of transformational leadership beyond the effects of transactional leadership", Journal of Business Research, 2014;67:1622-1629, https://doi.org/10.1016/j.jbusres.2013.09.006

Purwanto, A., Asbari, M., \& Santoso, P.(2019). Does Culture, Motivation, Competence, Leadership,Commitment Influence Quality Performance?. Jurnal Inovasi Bisnis, 6(2), 201-205. DOI: https://doi.org/10.35314/inovbiz.v7i2.1210

Purwanto, A., Asbari, M., \& Santoso, P.(2019).Influence of Transformational and Transactional Leadership Style toward Food Safety Management System ISO 22000:2018 Performance of Food Industry in Tangerang

Dirasah, Vol. 3, No. 1, Februari 2020 
Central Java. Jurnal Inovasi Bisnis, 6(2), 180-185. DOI: https://doi.org/10.35314/inovbiz.v7i2.1213

Purwanto, A., Asbari, M., \& Santoso, P.(2019).Pengaruh Kompetensi, Motivasi, Kepemimpinan, Komitmen dan Budaya Kerja Sistem Manajemen Integrasi ISO 9001, ISO 14000 dan ISO 45001 Pada Industri Otomotif. Jurnal Produktivitas Universitas Muhammadiyah Pontianak, 6(2), 158-166.

http://dx.doi.org/10.29406/jpr.v6i2.1798

Purwanto, A., Asbari, M., \& Santoso, P.(2019). Does Culture, Motivation, Competence, Leadership,Commitment Influence Quality Performance?. Jurnal Inovasi Bisnis, 6(2), 201-205. DOI: https://doi.org/10.35314/inovbiz.v7i2.1210

Purwanto, A., Asbari, M., \& Santoso, P.(2019).Influence of Transformational and Transactional Leadership Style toward Food Safety Management System ISO 22000:2018 Performance of Food Industry in Tangerang Central Java. Jurnal Inovasi Bisnis, 6(2), 180-185. DOI: https://doi.org/10.35314/inovbiz.v7i2.1213

Siti Salbiyah, Fitri Nuraini, Asyidatur Rosmaniar ( 2019 ). Motivation And Its Effect On Women's Lecturer Performance In University of Muhammadiyah Surabaya, SSRG International Journal of Economics and Management Studies (SSRG-IJEMS),6(9), 48-55

I. F.Segovia, B. Peidro, A.Fuentes, "Implementation of a food safety management system according to ISO 22000 in the food supplement industry: A case study", Food Control Journal,2014; 43: 28-34, https://doi.org/10.1016/j.foodcont.2014.02.042

R. Wahyuniardi, H.R. Nababan,"Pengaruh Kepemimpinan Transformasional Dan Budaya Organisasi Terhadap Kepuasan Kerja Serta Dampaknya Pada Kinerja Karyawan", Jurnal Teknik Industri, 2018;19:118-226, https://doi.org/10.22219/JTIUMM.Vol19.No2.118-126

Williams, Gavin, "Structural Equation Modeling Methodes In Strategy Research: Application and Issue" Research Methodology in Strategy and Management (Research Methodology in Strategy and 
Management, Vol. 1), Emerald Group Publishing Limited, Bingley, 2004; pp. 303-346. https://doi.org/10.1016/S1479-8387(04)01111-7

William Stoten, D. (2014), "Authentic leadership in English education: what do college teachers tell us?", International Journal of Educational Management, $\quad$ Vol. 28 No. 5, pp. 510-522. https://doi.org/10.1108/IJEM-04-2013-0049

Copyright (C) 2020 Journal Dirasah: Vol. 3, No. 1, Februari 2020, p-ISSN: 2615-0212, e-ISSN; 2621-2838

Copyright rests with the authors

Copyright of Jurnal Dirasah is the property of Jurnal Dirasah and its content may not be copied or emailed to multiple sites or posted to a listserv without the copyright holder's express written permission. However, users may print, download, or email articles for individual use. https://ejournal.iaifa.ac.id/index.php/dirasah 